\title{
Effect of high nonexchangeable aluminium on nitrogen and phosphorus availability in a humus-rich acid forest soil*
}

\author{
JAMES O. KLEMMEDSON and PETER BLASER \\ School of Renewable Natural Resources, University of Arizona, Tucson, AZ 85721, USA and Swiss \\ Federal Institute for Forest, Snow and Landscape Research, CH-8903 Birmensdorf ZH, Switzerland
}

Received 2 January 1990. Revised April 1990

Key words: exchangeable calcium, lime, organically-complexed aluminum, phosphate availability

\begin{abstract}
The effect of high nonexchangeable aluminum on availability of nitrogen $(\mathrm{N})$ and phosphorus $(\mathrm{P})$ was studied in a Cryptopodzolic soil (Cademario) derived from mica schist in southern Switzerland. The research involved a greenhouse pot experiment comparing growth of barley on soil samples of three soil layers (10- to 25-, 40- to 60- and 70- to $90 \mathrm{~cm}$ ) of the Cademario profile, representing a range of $\mathrm{Al}$ and organic matter properties, with the $10-$ to $40 \mathrm{~cm}$ layer of a profile of an acidic brown earth (Haplumbrept), derived from cherty limestone. The experiment, which included four nutrient treatments [check, $\mathrm{N}_{0}$ (PKS), $\mathrm{P}_{0}$ (NKS) and full (NPKS)], lime and no lime treatments and four replicates, was supplemented by soil chemical analysis. Results showed that liming alone produced greater yield responses in the Cademario soil than $\mathrm{N}$ or $\mathrm{P}$ added singly or together. On unlimed soils, barley yield for check, $\mathrm{N}_{0}$, and $\mathrm{P}_{0}$ treatments showed a positive linear relation with exchangeable $\mathrm{Ca}$ of soils and a negative linear relation with organically-complexed Al. Failure of liming to influence $P_{a v}$, especially when combined with $\mathrm{P}$ fertilization, suggests that $\mathrm{P}$ was quickly absorbed on highly active surfaces formed from initially exchangeable Al.
\end{abstract}

\section{Introduction}

Cryptopodzolic soils occurring on mica schist in the Ticino region of southern Switzerland are extremely rich in well-transformed organic matter, usually to a depth of more than $50 \mathrm{~cm}$ (Blaser, 1973). Generally, the entire profile of these soils is low in clay (i.e. $<10 \%$ ). Important properties for plant growth such as water holding capacity, $\mathrm{pH}$, exchangeable cations and anions, soil aeration and nutrient availability are con-

\footnotetext{
* This research is a cooperative effort of the Arizona Agricultural Experiment Stations, Journal Article No. 7100 and the Swiss Federal Institute for Forest, Snow and Landscape; it was supported by the National Science Foundation, USA, Grant No. INT-8304490, and the Swiss National Science Foundation, Grant No. 2.919-803.
}

ditioned largely by the organic fraction of the soil.

Similar soils occur elsewhere in Europe, chiefly in France (Coppenet, 1969; Dejou et al., 1968; 1969; Warenbourg et al., 1973). High aluminum status appears to play an important role in accumulation of organic matter and in nutritional characteristics of these soils. Those who have studied these soils (Blaser, 1973; Blaser and Klemmedson, 1987; Carballas et al., 1978; 1979; 1980) hypothesize that Al-organic matter complexes are very stable and that biodegradation proceeds slowly; as a consequence, humus mineralization is inhibited.

Following the above reasoning, this study was conducted to test the hypothesis that $\mathrm{N}$ and $\mathrm{P}$ are not readily available in soils derived from mica 
schist parent rocks and that availability of these nutrients is related to Al chemistry of the soil. The research approach was a greenhouse pot experiment comparing growth of barley on limed and unlimed soils derived from mica schist and cherty limestone ("Kieselkalk") parent materials, supplemented with soil chemical analysis.

\section{Materials and methods}

Soils for the experiment were obtained from two soil profiles near Lugano, Switzerland. Near the village of Cademario samples were collected from the 10- to 25-, 40- to 60- and $70-$ to $90 \mathrm{~cm}$ layers (hereafter referred to as $\mathrm{C} 1, \mathrm{C} 2$ and $\mathrm{C} 3$ in the text). These samples represent the range of $\mathrm{Al}$ and organic matter properties typical for soils formed on mica schist in this region. From a profile of an acidic brown earth (Haplumbrept) near Sagno, formed from a cherty limestone and locally described as Kieselkalk (De Quervain and Frey, 1967), the $10-$ to $40 \mathrm{~cm}$ layer was collected to serve as a control. The chemistry of both soils is described elsewhere (Blaser and Klemmedson, 1987).

Soils were air-dried and passed through a 6$\mathrm{mm}$ sieve to remove roots and coarse fragments prior to experimentation. The supply of available $\mathrm{N}$ and $\mathrm{P}$ was evaluated by a pot culture technique (Jenny et al., 1950) using barley (Hordeum vulgare L. var. Charlottetown) as the test plant in a $4 \times 2 \times 4 \times 4$ factorial randomized block experiment with soils, lime treatment, and nutrient treatment as fixed effects. Plastic pots were filled with $300 \mathrm{~g}$ of soil (oven-dry basis) to which lime (or no lime) and various combinations of nutrients as solutions had been added individually to each pot. For pots designated to receive lime, an amount of reagent grade $\mathrm{CaCO}_{3}$ sufficient to raise the soil $\mathrm{pH}$ to about 6.2 was mixed into the soil for each pot. Four nutrient treatments with four replicates each were used (Table 1). Soil that received the full treatment was assumed to supply test plants with sufficient nutrients for an optimum yield.

Five barley plants per pot were grown from seed and given tap water as required. Pots were arranged on a greenhouse table in randomized

Table 1. Nutrient treatments of the pot experiment

\begin{tabular}{lllll}
\hline Treatment $^{\mathrm{a}}$ & $\begin{array}{l}\text { Nutrients } \\
\text { added }\end{array}$ & \multicolumn{3}{l}{ Treatment recipe } \\
\cline { 3 - 5 } & & & $\begin{array}{l}\text { Nutrient } \\
\text { Rate, } \\
(\mathrm{kg} / \mathrm{ha})\end{array}$ & Form \\
\hline Check & - & $\mathrm{N}$ & 300 & $\mathrm{NH}_{4} \mathrm{NO}_{3}$ \\
Full & $\mathrm{NPKS}$ & $\mathrm{P}$ & 300 & $\mathrm{Ca}_{2}\left(\mathrm{H}_{2} \mathrm{PO}_{4}\right)_{2} \mathrm{H}_{2} \mathrm{O}$ \\
$\mathrm{N}_{0}$ & PKS & $\mathrm{K}$ & 100 & $\mathrm{~K}_{2} \mathrm{SO}_{4}$ \\
$P_{0}$ & $\mathrm{NKS}$ & $\mathrm{S}$ & 40 & $\mathrm{~K}_{2} \mathrm{SO}_{4}$ \\
\hline
\end{tabular}

${ }^{a}$ All treatments were applied with and without lime.

block fashion. Shoots were harvested after 42 days, oven-dried for 48 hours at $70^{\circ} \mathrm{C}$, and weighed. Mean dry weight per pot was computed for each soil-lime-nutrient combination. After harvesting, soil samples were taken from replicates 1 and 4 for chemical analysis. Exchangeable and extractable elements were obtained following end-over-end shaking of the soil using a 1:10 soil/solution ratio. Extraction time was 1 hour. Extractants were as follows:

Exchangeable elements

Extractable elements

$\mathrm{NO}_{3}^{-}, \mathrm{SO}_{4}^{2-}$ and $\mathrm{NH}_{4}^{+}$ Available $\mathrm{P}$

Total P

$\mathrm{Al}$ (organic)

Element determinations Cations

$\mathrm{NO}_{3}^{-}, \mathrm{SO}_{4}^{2-}$
$-1 N \mathrm{KCl}$

$-0.5 \mathrm{M}$ ammonium acetate, $0.02 M$ EDTA, PH 4.65 (Lakanen and Ervio, 1971) - distilled water

- $\mathrm{NaHCO}_{3}$ (Olsen and Sommers, 1982)

- fusion with $\mathrm{Na}_{2} \mathrm{CO}_{3}$ (Olsen and Sommers, 1982)

- calculated difference between extractable and exchangeable $\mathrm{Al}$ (Blaser and Klemmedson, 1987)

- ICP spectroscopy (Bausch and Lomb ARL 3580)

- single column IC 


\begin{tabular}{|c|c|}
\hline $\mathrm{NH}_{4}^{+}$ & $\begin{array}{l}\text { - colorimetrically } \\
\text { using the } \\
\text { indophenol blue } \\
\text { method (Keeney } \\
\text { and Nelson, } \\
\text { 1982) }\end{array}$ \\
\hline Organic $\mathrm{C}$ and $\mathrm{N}$ & $\begin{array}{l}\text { - dry combustion } \\
\text { with a "Heräus } \\
\text { C, H, N-Rapid" } \\
\text { analyzer }\end{array}$ \\
\hline $\mathrm{PO}_{4}^{-}$ & $\begin{array}{l}\text { - molybdopho- } \\
\text { sphoric blue } \\
\text { method (Jackson, } \\
1958 \text { ) }\end{array}$ \\
\hline$P$ in barley shoots & $\begin{array}{l}\text { - vanado-molybdo- } \\
\text { phosphoric } \\
\text { yellow color } \\
\text { method following } \\
\text { dry ashing } \\
\text { (Jackson, 1958) }\end{array}$ \\
\hline
\end{tabular}

\section{Results}

\section{Absolute and relative yields of barley}

Although the barley variety used was selected for its tolerance to acid soils, it did not grow well under the experimental conditions. Dry weight yields of plants were low for the entire experiment (Table 2). Even so, yield differences among treatments were marked. For the check treatment, the pattern of yield with depth in
Cademario soils was not what one would expect for a normal soil (i.e. highest yield was obtained from the $70-$ to $90-\mathrm{cm}$ soil layer). Yields for soils receiving the full treatment also were unusual. In theory, the full treatment should produce an optimum yield such that relative yields (ratio of $X_{0}$ yield to full treatment yield) for $N_{0}$ and $P_{0}$ treatments provide an accurate expression of the soil's ability to supply $\mathrm{N}$ and $\mathrm{P}$ (Jenny et al., 1950). Obviously, the nutrients added in the full treatment did not always provide optimum conditions, especially in limed soils (Table 2). With these raw yields, relative yields calculated for $\mathrm{N}$ and $\mathrm{P}$ frequently exceeded $100 \%$.

Because relative yields based on full treatment yields are difficult to interpret when this situation prevails, relative yields were calculated for all soils based on the unlimed checks (i.e. yield of the check treatment for each soil $=100 \%$, Table 3 ). These data indicate that for unlimed soils the relative yield for the $N_{0}$ treatment was significantly higher than that of the $\mathrm{P}_{0}$ treatment only in the reference soil from Sagno. For the C1 soil, both treatments influenced growth similarly, whereas for the $\mathrm{C} 2$ and $\mathrm{C} 3$ soils, the $\mathrm{P}_{0}$ treatment had a much more pronounced effect on growth than the $\mathrm{N}_{0}$ treatment.

Liming $\mathrm{C} 1$ and $\mathrm{C} 2$ soils without addition of $\mathrm{N}$ and $\mathrm{P}$ resulted in yields that were remarkably higher than yields for the full treatment of the unlimed soils. In the $\mathrm{C} 3$ soil, these treatments (i.e. lime alone and full treatment alone) had about the same effect. The stimulating effect of

Table 2. Dry weight yield ( $\mathrm{g} / \mathrm{pot}$ ) of barley shoots for Cademario and Sagno soils with various nutrient treatments. The data are means $\pm \mathrm{SE} ; \mathrm{n}=4$

\begin{tabular}{|c|c|c|c|c|c|}
\hline \multirow[t]{2}{*}{ Soil } & \multirow{2}{*}{$\begin{array}{l}\text { Soil layer, } \\
(\mathrm{cm})\end{array}$} & \multicolumn{4}{|c|}{ Nutrient treatment } \\
\hline & & Check & $\mathrm{N}_{0}$ & $P_{11}$ & Full \\
\hline \multicolumn{6}{|l|}{ Unlimed } \\
\hline \multirow[t]{3}{*}{ Cademario } & $10-25$ & $0.12 \pm 0.01$ & $0.18 \pm 0.02$ & $0.18 \pm 0.01$ & $0.15 \pm 0.02$ \\
\hline & $40-60$ & $0.03 \pm 0.01$ & $0.04 \pm 0.01$ & $0.15 \pm 0.02$ & $0.20 \pm 0.02$ \\
\hline & $70-90$ & $0.16 \pm 0.03$ & $0.28 \pm 0.05$ & $0.34 \pm 0.02$ & $0.40 \pm 0.04$ \\
\hline Sagno & $10-40$ & $0.37 \pm 0.04$ & $0.75 \pm 0.05$ & $0.48 \pm 0.03$ & $0.72 \pm 0.0 \mathrm{I}$ \\
\hline \multicolumn{6}{|l|}{ Limed } \\
\hline \multirow[t]{3}{*}{ Cademario } & $10-25$ & $0.28 \pm 0.04$ & $0.38 \pm 0.02$ & $0.28 \pm 0.02$ & $0.50 \pm 0.02$ \\
\hline & $40-60$ & $0.45 \pm 0.06$ & $0.75 \pm 0.05$ & $0.40 \pm 0.01$ & $0.50 \pm 0.04$ \\
\hline & $70-90$ & $0.37 \pm 0.02$ & $0.60 \pm 0.04$ & $0.34 \pm 0.05$ & $0.51 \pm 0.06$ \\
\hline Sagno & $10-40$ & $0.53 \pm 0.04$ & $1.13 \pm 0.06$ & $0.56 \pm 0.04$ & $0.95 \pm 0.06$ \\
\hline
\end{tabular}


Table 3. Relative yield $(\%)$ of the unlimed and limed soils based on the yield of unlimed check (i.e. $=100 \%)$

\begin{tabular}{|c|c|c|c|c|c|}
\hline \multirow[t]{2}{*}{ Soil } & \multirow{2}{*}{$\begin{array}{l}\text { Soil layer, } \\
(\mathrm{cm})\end{array}$} & \multicolumn{4}{|c|}{ Nutrient treatment } \\
\hline & & Check & $\mathrm{N}_{0}$ & $\mathbf{P}_{0}$ & Full \\
\hline \multicolumn{6}{|l|}{ Unlimed } \\
\hline \multirow[t]{3}{*}{ Cademario } & $10-25(\mathrm{C} 1)$ & 100 & 154 & 147 & 129 \\
\hline & $40-60(C 2)$ & 100 & 154 & 592 & 785 \\
\hline & $70-90(\mathrm{C} 3)$ & 100 & 172 & 212 & 244 \\
\hline Sagno & $10-40$ & 100 & 203 & 130 & 197 \\
\hline \multicolumn{6}{|l|}{ Limed } \\
\hline \multirow[t]{3}{*}{ Cademario } & $10-25(\mathrm{C} 1)$ & 234 & 319 & 238 & 421 \\
\hline & $40-60(\mathrm{C} 2)$ & 1742 & 2900 & 1542 & 1935 \\
\hline & $70-90(\mathrm{C} 3)$ & 226 & 369 & 220 & 312 \\
\hline Sagno & $10-40$ & 143 & 307 & 153 & 259 \\
\hline
\end{tabular}

lime was highest in the $\mathrm{C} 2$ soil where yield increased by $1742 \%$. In the Sagno soil the response to lime was rather small.

In the limed soils, the relative yield for the $\mathrm{N}_{0}$ treatment was higher in all soils than that for the $\mathrm{P}_{0}$ treatment, and except for soil $\mathrm{C} 1$ was also higher than that for the full treatment. This cursory analysis of the barley yield data suggests the $40-60 \mathrm{~cm}$ layer of the Cademario soil is of critical interest and that lime and $\mathrm{P}$ are important to its fertility.

\section{Analysis of yield response}

For insight to the soil parameters which influenced growth response of barley, yield was related to soil chemical properties measured in the samples at the end of the experiment. Perti- nent chemical properties of amended and unamended soil samples are shown in Table 4.

\section{Unlimed soils}

In view of the large yield increase noted above for barley growing on limed soils, one should expect a close relation between barley yield and exchangeable $\mathrm{Ca}$ content of the unlimed soils. This, in fact, was the case as shown in Figure 1. Raw barley yields for check, $\mathrm{N}_{0}$ and $\mathrm{P}_{0}$ treatments were linearly dependent on exchangeable $\mathrm{Ca}$ in the four soils. Compared with the check treatment the larger intercept of the $P_{0}$-curve indicates that addition of $\mathrm{N}$ resulted in a general yield increase of approximately $0.13 \mathrm{~g} /$ pot, but still growth depended primarily on exchangeable $\mathrm{Ca}$. The most important result of the $\mathrm{P}_{0}$ treatment, however, is not revealed well by com-

Table 4. Chemical properties of limed and unlimed, unfertilized soils at the end of the experiment

\begin{tabular}{|c|c|c|c|c|c|c|c|c|c|c|c|c|c|}
\hline \multirow[t]{2}{*}{ Soil } & \multirow{2}{*}{$\begin{array}{l}\text { Lime } \\
\text { Treatment }\end{array}$} & \multirow[t]{2}{*}{$\mathrm{pH}$} & \multirow{2}{*}{$\frac{C_{\text {org }}}{(\mathrm{g} / \mathrm{kg})}$} & \multirow[t]{2}{*}{$\mathrm{N}$} & \multicolumn{9}{|c|}{ Exchangeable cations $(\mathrm{mg} / \mathrm{kg})$} \\
\hline & & & & & $\mathrm{Ca}$ & Mg & Al & $\mathrm{Al}_{\text {Lak }}{ }^{\mathrm{a}}$ & $P_{\text {tot }}$ & $P_{a v}$ & $\mathrm{NO}_{3}$ & $\mathrm{NH}_{4}$ & $\mathrm{SO}_{4}$ \\
\hline \multicolumn{14}{|l|}{ Cademario } \\
\hline \multirow[t]{2}{*}{$10-25 \mathrm{~cm}$} & no lime & 3.74 & 97 & 6.2 & 183 & 31 & 725 & 2766 & 706 & 4.2 & 380 & 28 & 47 \\
\hline & lime & 5.35 & - & - & 3847 & 34 & 10 & 2226 & 709 & 2.8 & 300 & 61 & 128 \\
\hline \multirow[t]{2}{*}{$40-60$} & no lime & 4.22 & 69 & 4.2 & 73 & 12 & 434 & 2995 & 728 & 1.3 & 34 & 23 & 40 \\
\hline & lime & 5.46 & - & - & 2454 & 14 & 15 & 2867 & 696 & 2.0 & 9 & 16 & 140 \\
\hline \multirow[t]{2}{*}{$70-90$} & no lime & 4.72 & 39 & 2.7 & 261 & 11 & 165 & 1654 & 563 & 2.0 & 16 & 7 & 82 \\
\hline & lime & 5.59 & - & - & 1302 & 9 & 16 & 1653 & 542 & 2.2 & 6 & 6 & 156 \\
\hline \multicolumn{14}{|l|}{ Sagno } \\
\hline \multirow[t]{2}{*}{$10-40$} & no lime & 4.27 & 24 & 1.7 & 540 & 21 & 200 & 801 & 238 & 7.4 & 20 & 10 & 66 \\
\hline & lime & 5.41 & - & - & 1514 & 15 & 7 & 657 & 223 & 7.6 & 14 & 13 & 81 \\
\hline
\end{tabular}

${ }^{\mathrm{a}} \mathrm{NH}_{4}$-Ac-EDTA extract. 


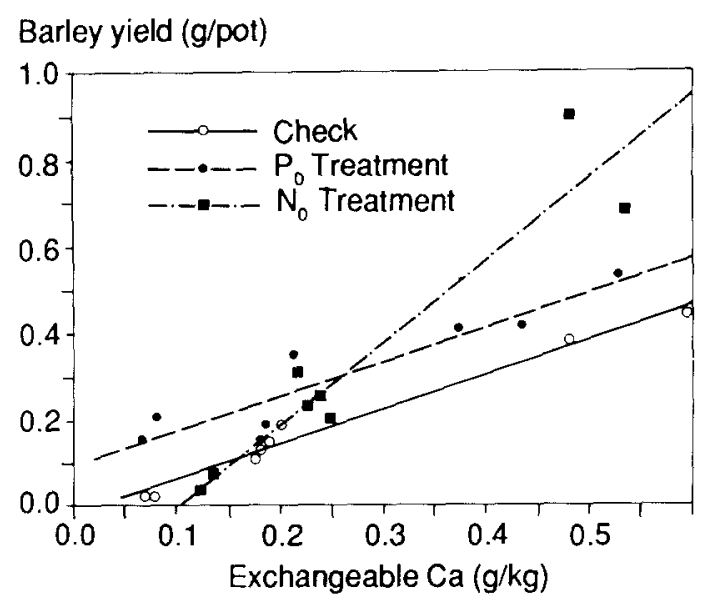

Fig. 1. Dependence of barley yield on exchangeable $\mathrm{Ca}$ in the unlimed soils.

parison of raw yields. Relative yields for unlimed soils (Table 3) show that the strongest response to the $\mathrm{P}_{0}$ treatment was from the $\mathrm{C} 2$ soil. The 6-fold response in yield to this treatment was not much lower than the 8-fold response of the full treatment (Tables 2 and 3), and when compared with the $\mathrm{N}_{0}$ barley yield, indicates that in the absence of lime, $\mathrm{N}$ rather than $\mathrm{P}$, was the most deficient nutrient for this soil layer.

The regression for barley yield as a function of exchangeable $\mathrm{Ca}$ for soils with the $\mathrm{N}_{0}$ treatment (Fig. 1) had a steeper rate of yield increase than that for soils with the $\mathrm{P}_{0}$ treatment. The slope of this curve is larger by a factor 2.2 compared with slopes for the check and $P_{0}$ treatments. Based on the curve for the check treatment, some increase in yield should be expected with the $N_{0}$ treatment because of the addition of $\mathrm{Ca}(26 \mu \mathrm{g} / \mathrm{pot})$ in the nutrient treatment (i.e. $\mathrm{P}$ added as monocalcium phosphate), but most of the yield response can be attributed to $\mathrm{P}$ added as part of the treatment. Despite the large yield response of $103 \%$ for the Sagno soil with the $\mathrm{N}_{0}$ treatment (Table 3), this soil behaves like the Cademario soil with respect to exchangeable $\mathrm{Ca}$, as manifested by the fit of the Sagno data to the regression line in Figure 1. Yield responses for the Cademario soils were still marked, ranging from 54 to $72 \%$ (Table 3 ).

To visualize the influence of aluminum on barley growth, yields were related to $\mathrm{KCl}$ exchangeable $\mathrm{Al}$, to $\mathrm{NH}_{4}$ Ac-EDTA-extractable
$\mathrm{Al}$, and to an $\mathrm{Al}$ fraction which is expressed by the difference between extractable and exchangeable Al. Based on evidence of recent studies (Blaser and Klemmedson, 1987), we suggest the latter fraction represents mainly $\mathrm{Al}$ which is complexed by organic matter $\left(\mathrm{Al}_{\text {org }}\right)$. Interestingly, of these three $\mathrm{Al}$ fractions, $\mathrm{Al}_{\text {org }}$ showed the best correlation $\left(\mathrm{r}^{2}=0.83\right.$ to 0.91$)$ with barley yield for the treatments portrayed in Figure 2. Correlations for the regressions between barley yield and $\mathrm{KCl}$-exchangeable and $\mathrm{NH}_{4}$ Ac-EDTA extractable Al were rather poor.

As mentioned above, the full treatment produced unusual yield responses, suggesting that it was indeed not an optimum treatment. This was particularly true for limed soils. In unlimed Cademario soils, overall response of barley to the full treatment was similar to that of the $P_{0}$ treatment, whereas the full treatment yield response for the Sagno soil was closer to that of the $\mathrm{N}_{0}$ treatment. In limed soils the full treatment yields for the C2, C3 and Sagno soils all showed negative interaction between $\mathrm{N}$ and $\mathrm{P}$ (Tables 2 and 3). This also was apparent for the unlimed $\mathrm{C} 1$ soil. This clearly suggests that of the two nutrients evaluated in this experiment, $P$ was the key nutrient controlling nutrition of barley in these soils.

The relation between barley yield and $\mathrm{Ca}_{\text {exch }}$ as well as that between yield and $\mathrm{Al}_{\text {org }}$ described above suggests that barley yield was related to the $\mathrm{Al}_{\text {org }} / \mathrm{Ca}_{\mathrm{exch}}$ ratio. Data for this relation was

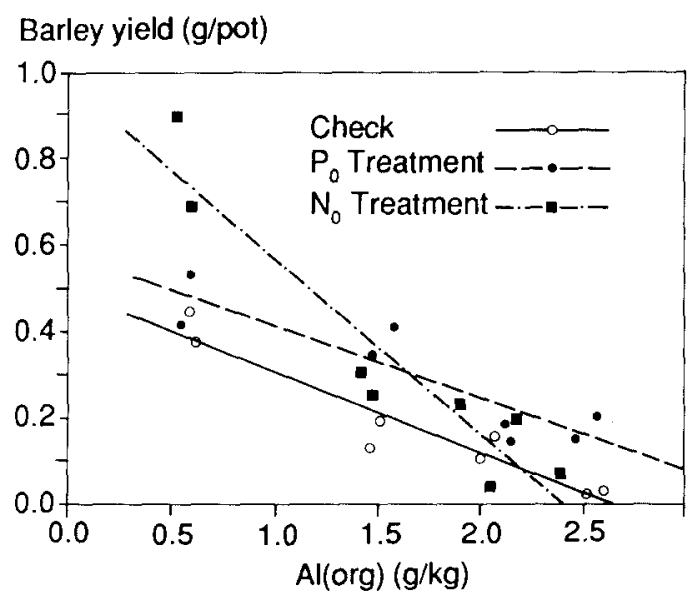

Fig. 2. Yield of barley as a function of $\mathrm{Al}_{\text {org }}$ in the unlimed soils. 
graphed (Fig. 3) for each treatment (unlimed soils) and fitted to the model $\mathrm{Y}=1 /(\mathrm{a}+\mathrm{bX})$ where $\mathrm{Y}$ is barley yield and $\mathrm{X}$ is the $\mathrm{Al}_{\text {org }} / \mathrm{Ca}_{\text {exch }}$ ratio. When expressed in the linear form (1/ $Y=a+b X)$, the intercepts for regressions of various treatments did not differ significantly from zero. Moreover, fitting the model without the intercept improved the statistical fit for all treatments. Inspection of the curves and regression statistics (Fig. 3) reveals good fits (visually and statistically) of the data for the check and $\mathrm{N}_{0}$ treatments. The fits for $\mathrm{P}_{0}$ and full treatments (curve for full treatment not shown here) were less satisfactory and regression coefficients for these curves differed significantly from those for the check and $\mathrm{N}_{0}$ treatments. Addition of $\mathrm{N}$ in the $\mathrm{P}_{0}$ and full treatments increased yield sufficiently for the $\mathrm{C} 1$ soil (high $\mathrm{Al}_{\text {org }} / \mathrm{Ca}_{\text {exch }}$ values) relative to that of the other soils that a poor fit of curves to the data resulted. Significantly, curves in Figure 3 show that as the $\mathrm{Al}_{\text {org }} / \mathrm{Ca}_{\text {exch }}$ ratio drops below a value of about five, yield increases rapidly. The explanation for this relationship presumably lies in an understanding of the nutrition of barley in these soils. Relating barley yield to other soil parameters (Table 4 ) provides no explanation.

\section{Limed soils}

In the presence of lime, the raw yield response of barley to the $\mathrm{P}_{0}$ treatment was nonsignificant for all soils (Table 2). By contrast, the $\mathrm{N}_{0}$ treatment stimulated barley growth and produced marked yield increases for all soils. Thus, once soils were limed, addition of $\mathbf{P}$ produced good yield responses ranging from $36 \%$ for the $\mathrm{C} 1$ soil to $113 \%$ for the Sagno soil.

Table 5 shows available $P\left(P_{a v}\right)$ status of unlimed soils for the four treatments. There was good agreement in $P_{a v}$ between check- and $P_{0}$ treatments among all soils; $P_{a v}$ was especially low in $\mathrm{C} 2$ and $\mathrm{C} 3$ soils for these treatments, averaging only about 1.3 and $2.0 \mathrm{mg} / \mathrm{kg}$ in absolute terms and only 0.2 and $0.4 \%$ of total $P$, respectively. Available $\mathrm{P}$ was about three-fold higher (absolute and relative terms) in $\mathrm{C} 1$ than in $\mathrm{C} 2$ or C3 soils, even though $P_{\text {tot }}$ was similar (Table 5). In the Sagno soil, $P_{a y}$ for the check- and $P_{0}$ treatments was up to four times greater and $\left(\mathrm{P}_{\mathrm{av}}\right.$ as a percentage of $P_{\text {tot }}$ was 8 to 15 times greater)
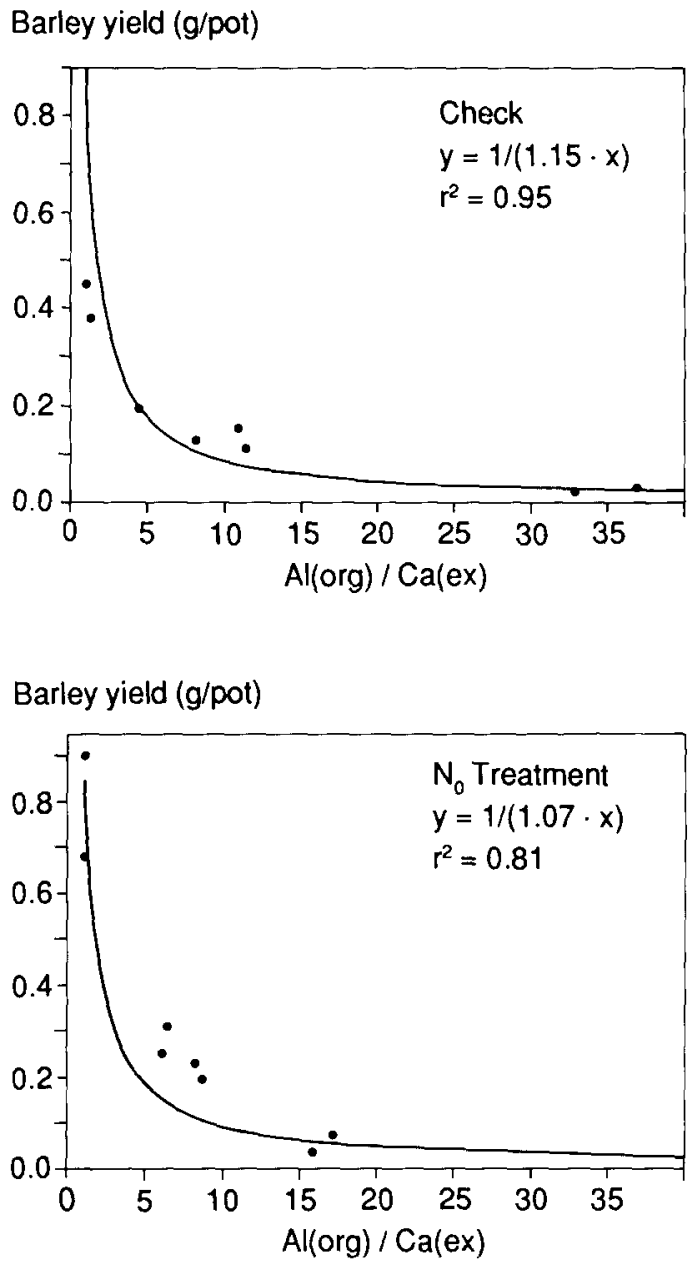

Barley yield (g/pot)

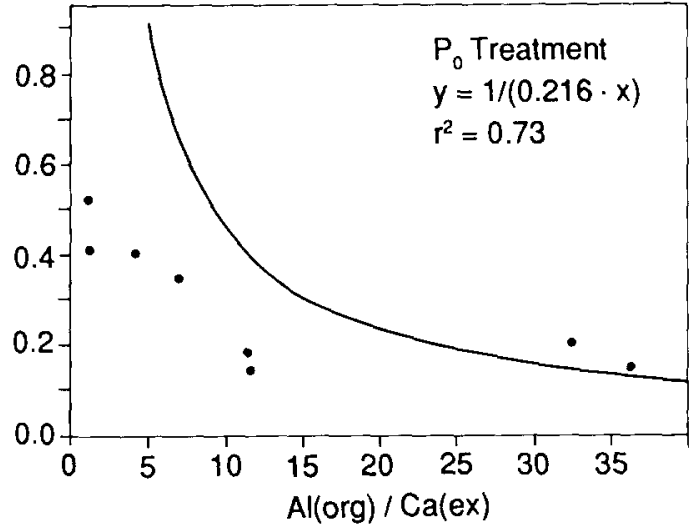

Fig. 3. Yield of barley shoots grown in unlimed soils as a function of $\mathrm{Al}_{\text {org }} / \mathrm{Ca}_{\text {exch }}$ ratios for a check, b $\mathrm{N}_{0}$ and $\mathbf{c} \mathrm{P}_{0}$ treatments. Regression coefficients were significant at $p<$ 0.001 for the check and $\mathrm{N}_{0}$ treatments and at $p<0.005$ for the $\mathrm{P}_{01}$ treatment. 
Table 5. Availability of phosphorus in unlimed soils as a function of nutrient treatment at the end of the experiment

\begin{tabular}{|c|c|c|c|c|c|}
\hline \multirow[t]{2}{*}{ Soil } & \multirow[t]{2}{*}{ Treatment } & \multicolumn{2}{|l|}{$\mathrm{P}_{\mathrm{av}}$} & \multicolumn{2}{|c|}{ Increase in $\mathrm{P}_{\mathrm{av}}$ with added $\mathrm{P}_{\mathrm{t}, \mathrm{r}}$} \\
\hline & & $\mathrm{mg} / \mathrm{kg}$ & $\%$ of $\mathrm{P}_{101}$ & $\mathrm{mg} / \mathrm{kg}$ & $\%$ of added $\mathrm{P}$ \\
\hline \multicolumn{6}{|l|}{ Cademario } \\
\hline \multirow[t]{4}{*}{$10-25 \mathrm{~cm}$} & check & 4.2 & 0.6 & - & - \\
\hline & $N_{0}$ & 11.4 & 1.6 & 7.2 & 5.4 \\
\hline & $P_{13}$ & 4.0 & 0.6 & - & - \\
\hline & full & 11.0 & 1.4 & 6.8 & 5.1 \\
\hline \multirow[t]{4}{*}{$40-60$} & check & 1.3 & 0.2 & - & - \\
\hline & $\mathrm{N}_{0}$ & 5.0 & 0.6 & 3.7 & 2.8 \\
\hline & $P_{11}$ & 1.7 & 0.2 & - & - \\
\hline & full & 5.0 & 0.6 & 3.7 & 2.8 \\
\hline \multirow[t]{4}{*}{$70-90$} & check & 2.0 & 0.4 & - & - \\
\hline & $\mathbf{N}_{0}$ & 5.5 & 0.8 & 3.5 & 2.6 \\
\hline & $\mathbf{P}_{0}$ & 2.2 & 0.4 & - & - \\
\hline & full & 5.6 & 0.8 & 3.6 & 2.7 \\
\hline \multicolumn{6}{|l|}{ Sagno } \\
\hline \multirow[t]{4}{*}{$10-40$} & check & 7.4 & 3.1 & - & - \\
\hline & $\mathbf{N}_{0}$ & 73.4 & 19.2 & 66.0 & 49.3 \\
\hline & $\mathbf{P}_{0}$ & 6.8 & 2.9 & - & - \\
\hline & full & 72.3 & 18.6 & 64.9 & 48.5 \\
\hline
\end{tabular}

than that for Cademario soils. Close agreement also occurred in $\mathrm{P}_{\mathrm{av}}$ between the $\mathrm{N}_{0}$ - and full treatments. The addition of $P$ in these treatments resulted in a 3 - to 4 -fold increase in $\mathrm{P}_{\mathrm{av}}$ in the Cademario soils and a 10-fold increase in $\mathrm{P}_{\mathrm{av}}$ in the Sagno soil. However, of the $\mathrm{P}$ added as part of the nutrient treatment, only 3 to $5 \%$ was recovered or remained as soil $\mathrm{P}_{\mathrm{av}}$ at the end of the experiment in Cademario soils, while $49 \%$ was recovered in the Sagno soil. This suggests that much of the $\mathrm{P}$ added to the Cademario soils was fixed during the $42 \mathrm{~d}$ experimental period. Presumably, $\mathrm{Al}_{\text {org }}$ which was 2- to 4 -fold higher in Cademario than in Sagno soils, played a role in this process (Boudot et al., 1986). Liming together with $\mathrm{P}$ fertilization $\left(\mathrm{N}_{0}\right.$ and full treatments) had very little effect on $\mathrm{P}_{\mathrm{av}}$ (results not shown here).

\section{Discussion}

The association between barley yield and $\mathrm{Ca}_{\text {exch }}$ and $\mathrm{Al}_{\text {org }}$ shown in Figures 1 and 2 was consistent among all nutrient treatments. It was especially strong for the $\mathrm{N}_{0}$ treatment. The addition of $\mathrm{P}$ with this treatment produced the greatest yield increase in soils with the highest amounts of exchangeable $\mathrm{Ca}$ and the lowest amounts of complexed $\mathrm{Al}$ (i.e. $\mathrm{Al}_{\text {org }}$ ). This result is inconsistent with other research on Al-rich, highly organic soils (Borie and Zunino, 1983; Boudot et al., 1986). The strong negative relation between barley yield and $\mathrm{Al}_{\text {org }}$ is not inconsistent with research that has shown detoxification of $\mathrm{Al}$ and improved plant growth with addition of humic acids or organic matter (see review of Tan and Binger, 1986). Most of that research involved nutrient solutions or soils low in organic matter, hence is not directly comparable with our study.

Results of these experiments show that liming alone produced greater yield responses in the Cademario soils than $\mathrm{N}$ or $\mathrm{P}$ added singly or together. With addition of lime to these soils, $\mathrm{pH}$ and exchangeable $\mathrm{Ca}$ were increased and exchangeable $\mathrm{Al}$ was markedly decreased, as others (e.g. Sims and Ellis, 1983) have observed. Simultaneously, the fraction designated $\mathrm{Al}_{\text {org }}$ increased for all soils. This new $\mathrm{Al}_{\text {org }}$, amounting to an increase of 9 to $17 \%$, evidently represents Al that was in exchangeable form before liming. The large increase in barley yield with liming, especially for the $\mathrm{C} 2$ soil (Table 3 ), apparently is associated with removal of $\mathrm{Al}_{\text {exch }}$ (Table 4) and 
hence reduction in activity of aluminium in solution. Plotting barley yield against $\mathrm{Al}_{\text {org }} / \mathrm{Ca}_{\text {exch }}$ for limed as well as unlimed soils shows that the model employed for unlimed soils (Fig. 3) is valid also for limed soils (Fig. 4).

Failure of liming to influence $\mathrm{P}_{\mathrm{av}}$ more substantially, especially when combined with $\mathrm{P}$ fertilization, strongly suggests that phosphate was quickly absorbed on new highly active phosphate absorbing surfaces formed from initially exchangeable Al (Haynes, 1982; Reeve and Summer, 1970; Sims and Ellis, 1983) or by formation of organic matter-P complexes through $\mathrm{Al}$ -
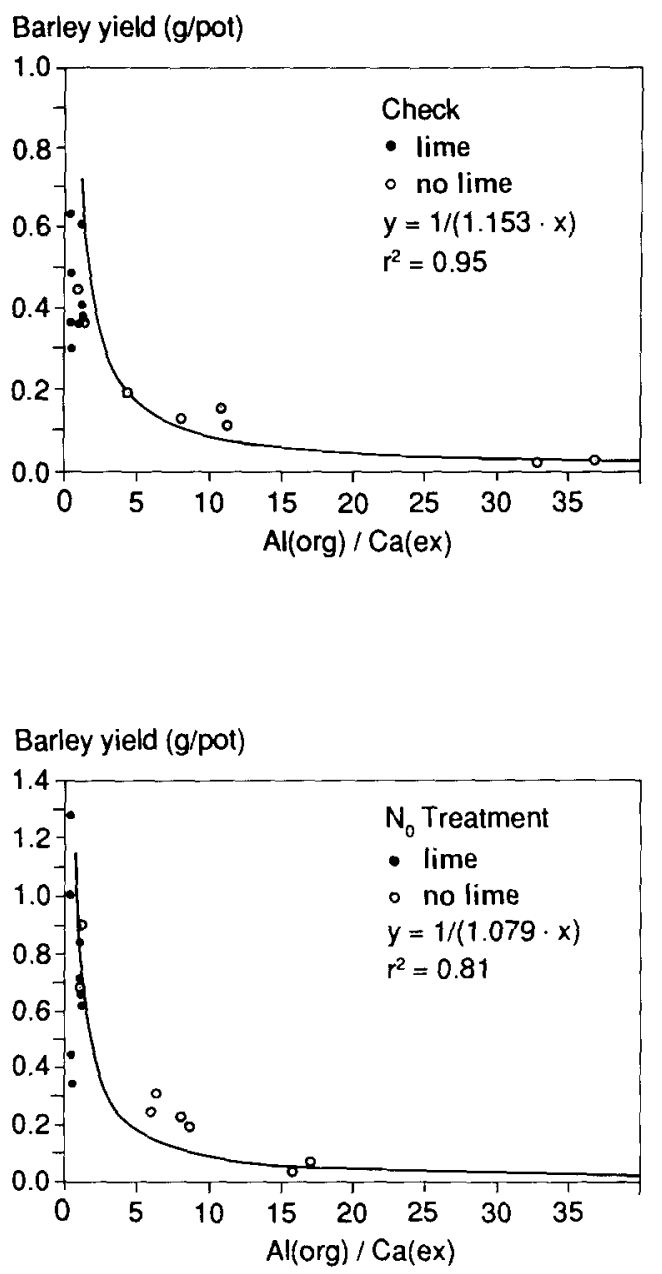

Fig. 4. Yield of barley shoots grown in limed and unlimed soils as a function of $\mathrm{Al}_{\text {org }} / \mathrm{Ca}_{\text {exch }}$ ratios for a check and $\mathbf{b ~} \mathrm{N}_{0}$ treatments. Regresssion coefficients were significant at $p<$ 0.001 . bridges (Borie and Zunino, 1983). Increase in barley yield may then be interpreted as a primary response to reduced Al toxicity. A common characteristic of $\mathrm{Al}$ toxicity, which occurs in the presence of monomeric Al (Blamey et al., 1983), is inhibition of $P$ uptake and translocation by plants (Foy and Fleming, 1978; Jones and Fox, 1978). Thus, the yield response noted with liming may have reflected increased uptake of the limited amounts of $\mathrm{P}_{\mathrm{av}}$ as Al toxicity was reduced (Haynes, 1982). As Haynes (1982) noted, in acid soils it is often difficult, if not impossible, to separate the effects of Al toxicity and $\mathrm{P}$ deficiency. Moreover, our evidence for Al toxicity (swollen, stubby and gnarled roots, absence of root hairs) obtained in auxiliary pot experiments with corn seedlings, although manifesting some of the characteristic symptoms in appearance of roots (Foy and Fleming, 1978) was inconclusive (Klemmedson and Blaser, unpublished data).

Organic matter complexed by $\mathrm{Al}$ in the Cademario soil represents a pool of trapped nutrients. Companion studies (Brunner and Blaser, 1989) have shown that Al probably plays a central role in mineralization of organic matter of the Cademario soils. Although $\mathrm{N}$ metabolism was not inhibited, as shown for similar soils (Boudot and Chone, 1985), Al seems to influence degradation of water-soluble organic compounds in the Cademario soil, affecting both growth rate and biomass (Brunner and Blaser 1989). This would, of course, impede release of nutrients for uptake by plants (Boudot et al., 1986). If the organic matter of the Cademario soils does represent the major pool of $P$, as well as of $\mathrm{N}$ and probably $\mathrm{S}$, liming can be expected to stimulate mineralization of these compounds (Awan, 1964; Halstead et al., 1963) by creating a more favorable environment for microbial activity (Anderson, 1980). Although improved $\mathrm{P}$ mineralization by virtue of liming may have contributed to increased barley yields, we have no direct evidence of this. Increase in $\mathrm{SO}_{4}$ with liming (Table 4) is perhaps the best evidence of improved mineralization of organic matter and $\mathrm{C} / \mathrm{N}$ as well as $\mathrm{C} / \mathrm{P}$ ratios were in a range that net mineralization rather than immobilization could be expected (Enwezor, 1976; Jansson and Persson, 1982). 


\section{Acknowledgements}

The assistance of G. Jelmini and A. Martinoni from the Sottostazione federale di ricerche agronomiche, Cadenazzo, Switzerland, Annie Diarra, Swiss Federal Institute for Forest, Snow and Landscape Research and Justine McNeil and Brian Wienhold, University of Arizona, is appreciated.

\section{References}

Anderson G 1980 Assessing organic phosphorus in soils. In The Role of Phosphorus in Agriculture. Eds. F E Khasawneh et al. pp 411-431. Am. Soc. Agron., Madison, WI.

Awan A B 1964 Effect of lime on availability of phosphate in Zamorano soils. Soil Sci. Soc. Am. Proc. 28, 672-673.

Blamey F P C, Edwards D G and Asher C J 1983 Effects of aluminum, $\mathrm{OH}: \mathrm{Al}$ and $\mathrm{P}: \mathrm{Al}$ and $\mathrm{P}: \mathrm{Al}$ molar ratios, and ionic strength on soybean root elongation in solution culture. Soil Sci. 136, 197-207.

Blaser P 1973 Die Bodenbildung auf Silikatgestein im südlichen Tessin. Mitt. Eidg. Anst. Forstl. Versuchswesen 49, 253-340.

Blaser P and Klemmedson J O 1987 Die Bedeutung von hohen Aluminiumgehalten für die Humusanreicherung in sauren Waldböden. Z. Pflanzenernaehr. Bodenkd. 150, 334-341.

Bohn H L, McNeal B L and O'Connor G A 1979 Soil Chemistry. Wiley, New York.

Borie F and Zunino H 1983 Organic matter-phosphorus associations as a sink in P-fixation processes in allophanic soils of Chile. Soil Biol. Biochem. 15, 599-603.

Boudot J P and Chone T 1985 Internal nitrogen cycling in two humic-rich acidic soils. Soil Biol. Brochem. 17, 135142 .

Boudot J P, Bel Hadj B A and Chone T 1986 Carbon mineralization in andosols and aluminum-rich highland soils. Soil Biol. Biochem. 18, 457-461.

Bremner J M and Mulvaney C S 1982 Nitrogen-total. In Methods of Soil Analysis. Eds. A L Page et al. Part 2, 2nd Edition. Agronomy 9, 595-624.

Brunner W and Blaser P 1989 Mineralization of soil organic matter and added carbon substrates in two acidic soils with high non-exchangeable aluminum. Z. Pflanzenernaehr. Bodenkd. 152, 367-372.

Carballas M, Carballas A, Guitian-Ribera F and Carballas T 1980 Organo-metallic complexes in Atlantic humiferous soils. An. Edafol. Agrobiol. 39, 1033-1043.

Carballas T, Carballas M and Jacquin F 1978 Biodégradation et humification de la matière organique des sols humifers atlantiques. An. Edafol. Agrobiol. 37, 205-212.

Carballas M. Carballas T and Jacquin F 1979 Biodegradation and humification of organic matter in humiferous Atlantic soils. I. Biodegradation. An. Edafol. Agrobiol. 38, 16991717.

Coppenet M 1969 Les sols de la Galice comparés aux sols de la Bretagne occidentale. Sci. Sol 43-56.

Dejou J, Guyot J and Morizet J 1968 Juxtaposition de sols noirs, très riches en matière organique et de sols bruns acides sur leucogranites dans la région d'EymoutiersPeyrat-Le Château (Haute-Vienne). Ann. Agron. 19, 511 539.

Dejou J, Guyot J and Morizet J 1969 Les sols noirs, très riches en matieres organiques reposant sur leucogranites dans la region d'Eymoutiers-Peyrat-Le Chateau (HauteVienne). Ann. Agron. 20, 517-526.

De Quervain F and Frey D 1967 Geotechnische Karte der Schweiz 1:200000, Blatt Nr. 4, Bellinzona-St. Moritz. Kummerli und Frey. Geographischer Verlag, Bern.

Enwezor W O 1976 The mineralization of nitrogen and phosphorus in organic materials of varying $C: N$ and $C: P$ ratios. Plant and Soil 44, 237-240.

Foy C O and Fleming A L 1978 The physiology of plant tolerance to excess available aluminum and manganese in acid soils. In Crop Tolerance to Suboptimal Land Conditions. Ed. G A Jung. pp 301-328. Am. Soc. Agron., Madison, WI.

Halstead R L. Lapensee J M and Invarson K C 1963 Mineralization of soil organic phosphorus with particular reference to the effect of lime. Can. J. Soil Sci. 43, 97-106.

Haynes R J 1982 Effects of liming on phosphate availability in acid soils. Plant and Soil 68,289-308.

Jackson M L 1958 Soil Chemical Analysis. Prentice-Hall, Inc., Englewood Cliffs, NJ, $498 \mathrm{p}$

Jansson R J and Persson J 1982 Mineralization and immobilization of soil nitrogen. In Nitrogen in Agricultural Soils. Ed. F J Stevenson. pp 229-252. Agronomy Monograph No. 22. ASA-CSSA-SSSA, Madison, WI.

Jenny H, Vlamis $J$ and Martin W E 1950 Greenhouse assay of fertility in California soils. Hilgardia 20, 1-8.

Jones J P and Fox R L 1978 Phosphorus nutrition of plants influenced by manganese and aluminum uptake from an Oxisol. Soil Sci. 126, 230-236.

Keeney D R and Nelson D W 1982 Nitrogen-inorganic forms. In Methods of Soil Analysis. Eds. A L Page et al. Part 2, 2nd Edition. Agronomy 9, 643-693.

Lakanen E and Erviö R 1971 A comparison of eight extractants for the determination of plant avalable micronutrients in soils. Acta Agral. Fenn. 123, 12-13.

Olson S R and Sommers L E 1982 Phosphorus. In Methods of Soil Analysis. Eds. A L. Page et al. Part 2, 2nd Edition. Agronomy 9, 403-430.

Reeve N G and Sumner M E 1970 Effects of aluminum toxicity and phosphorus fixation on crop growth on $O x$ isols. In Natal. Soil Ser. Soc. Am. Proc. 34, 263-267.

Sims T T and Ellis B G 1983 Adsorption and availability of phosphorus following the application of limestone to an acid, aluminous soil. Soil Sci. Soc. Am, J. 47, 888-893.

Warenbourg F R, Lossaint P and Bottner P 1973 Levolution des sols dans une sequence bioclimatique mediterraneomontagnarde sur roche-mer siliceuse. Massif du Mont Aigoval. Bull. A.F.E.S. num. 1, 49-61. 